\title{
MICROBIAL INTERACTIONS IN THE DEVELOPMENT OF THE BIOMASS OF GLIRICIDIA $^{1}$
}

\author{
TAMIRIS APARECIDA DE CARVALHO SANTOS ${ }^{2}$, GEOVANIA DOS SANTOS MENEZES ${ }^{2}$, JESSICA SILVA \\ SANTOS $^{2}$, LARISSA DE SOUZA GOIS ${ }^{2}$, SÉRGIO LUIZ MENDONÇA NASCIMENTO ${ }^{3}$, REGINA HELENA \\ MARINO $^{2 *}$
}

\begin{abstract}
The objective of this work was to evaluate the interaction of microorganisms and phosphorus dosages in the development of gliricidia. The experimental design was completely randomized with six treatments (control, native microbial inoculant, and four arbuscular mycorrhizal fungi isolates: UFLA05 Gigaspora albida, UFLA351 - Rhizoglomus clarum, UFLA372 - Claroideoglomus etunicatum, and UFLA401 Acaulospora morrowiae), with four replicates. The parameters evaluated were: height plant, the number of branches, shoot and root dry mass matter, root length and volume, leaf phosphorus, mycorrhizal colonization, the number of spores of the arbuscular mycorrhizal fungi, the number of nodules of nitrogen fixing bacteria, and the presence of endophytic dark septate fungi, after 95 days of inoculation. The high mycorrhizal colonization of gliricidia does not guarantee an increase in biomass, which depends on the interaction of the arbuscular mycorrhizal fungi, the endophytic dark septate fungi, the nitrogen fixing bacteria, and the endophytic bacteria. Gliricidia was responsive to the inoculation of the native microbiota, UFLA372 and UFLA401. Mycorrhizal colonization by UFLA401 was influenced by the presence of nitrogen fixing bacteria. Gliricidia was not responsive to the inoculation of UFLA05 and UFLA351. The presence of the endophytic dark septate fungi did not inhibit mycorrhization and the formation of nodules of nitrogen fixing bacteria in gliricidia.
\end{abstract}

Keywords: Fabaceae. Arbuscular mycorrhizal fungi. Nitrogen-fixing bacteria. Endophytic.

\section{INTERAÇÃO MICROBIANA NO DESENVOLVIMENTO DA BIOMASSA DE GLIRICÍDIA}

RESUMO - O objetivo deste trabalho foi avaliar a interação de micro-organismos no desenvolvimento da gliricídia. O delineamento experimental utilizado foi inteiramente aleatorizado composto por seis tratamentos (controle; inoculante microbiano nativo e quatro isolados fúngicos micorrízicos arbusculares: UFLA05 Gigaspora albida, UFLA351 - Rhizoglomus clarum, UFLA372 - Claroideoglomus etunicatum e UFLA401 Acaulospora morrowiae), com quatro repetições. Os parâmetros avaliados foram: altura da planta, número de ramos, massa da matéria seca da parte aérea e da raiz, comprimento e volume de raiz, teor de fósforo foliar, colonização micorrízica, número de esporos de fungos micorrízicos arbusculares, número de nódulos de bactérias fixadoras de nitrogênio, presença de fungos endofíticos "dark septate", após 95 dias da inoculação. A elevada colonização micorrízica da gliricídia não garante incremento da biomassa, a depender da interação de fungos micorrízicos arbusculares, de fungos endofíticos "dark septate", de bactérias fixadoras do nitrogênio e de bactérias endofíticas. A gliricídia foi responsiva à inoculação da microbiota nativa, UFLA372 e UFLA401. A colonização micorrízica por UFLA401 foi influenciada pela presença de bactérias fixadoras do nitrogênio. A gliricídia não foi responsiva à inoculação de UFLA05 e UFLA351. A ocorrência de fungos endofíticos "dark septate" não inibiu a micorrização e a formação de nódulos de bactérias fixadoras do nitrogênio, em gliricídia.

Palavras-chave: Fabaceae. Fungo micorrízico arbuscular. Fixação biológica do nitrogênio. Endofítico.

\footnotetext{
${ }^{*}$ Corresponding author

${ }^{1}$ Received for publication in 01/15/2017; accepted in 08/07/2017.

Paper extracted from the scientific initiation work of the first author.

${ }^{2}$ Department of Agronomic Engineering, Universidade Federal de Sergipe, São Cristóvão, SE, Brazil; tamiriscarvalho12@gmail.com ORCID: 0000-0002-7804-7533, geovaniaa.menezes@gmail.com - ORCID: 0000-0002-8721-070X, jsksantos1991@gmail.com - ORCID: 0000-0001-8789-0146, lary18gois@gmail.com - ORCID: 0000-0003-2134-0509, rehmarino@hotmail.com - ORCID: 0000-0002-72953746.

${ }^{3}$ Laboratory of Inorganic Chemistry, Instituto Tecnológico e de Pesquisas do Estado de Sergipe, Aracaju, SE, Brazil; lab.inorganica@itps.se.gov.br-ORCID: 0000-0002-1931-6158.
} 


\section{INTRODUCTION}

The Gliricidia sepium (Jacq.) Walp is a treesized species belonging to the family Fabaceae that originated in Central America. It has been used for green manuring, wind breaking, hedging, wood production, and for recovery of degraded areas, since it tolerates acidic and low fertility (EIRAS; COELHO, 2011). In addition, due to its high protein content, gliricidia is used as a forage in the Brazilian Northeast (MARIN et al., 2006).

The protein content present in the biomass of the Fabaceae members is related to the biological fixation of nitrogen by diazotrophic bacteria, which are responsible for the amount of nitrogen that is directly available to the plant. Specifically in nutrient-poor soils, the fixation of nitrogen by the bacteria allows the plant to grow by promoting a buildup of mass matter via synthesis of amino acids and proteins (MOREIRA; SIQUEIRA, 2006). Florentino et al. (2014) cites that gliricia preferentially symbioses with the fast-growing rhizobia isolates, whose potential in the biological fixation of nitrogen can vary with the edaphoclimatic conditions of the region where the plant is grown. Further, a study by E Mello, Silva and Saggin-Júnior (2012) emphasizes that depending on the microorganism-plant interaction, the formation of nodules of nitrogen-fixing bacteria in the gliricidia can be stimulated by the presence of an arbuscular mycorrhizal fungi (AMF). Lastly, Tavares et al. (2012) observed that with a mycorrhizal colonization in Mimosa caesalpinaefolia Benth, there was an increase in the dry matter mass of the root nodules of the nitrogen-fixing bacteria by $1900 \%$.

The symbiosis between the mycorrhizal fungi and the fabaceae is important for the supply of nitrogen and phosphorus to the plant and to the nitrogen-fixing bacteria (TWUM-AMPOFO, 2008; JALONEN et al., 2013). Together, such symbiosis may favor growth and survival of plants in adverse conditions, such as drought (AUGÉ, 2001), a common occurrence in the Northeastern Brazil. However, the benefits of the fungi-plant interaction are not only related to nutrition. The arbuscular mycorrhizal fungi can promote soil aggregation through the action of a glycoprotein called glomalin, excreted by mycelia, which contributes to soil conservation (RUBIN; STÜRMER, 2015).

In addition to the nitrogen-fixing bacteria and the arbuscular mycorrhizal fungi, plants can be colonized by other microorganisms such as the endophytes. Santos and Varavallo (2011), in their literature review, report that the endophytes develop within the plant, without any visible symptoms of their presence, although they can promote the growth of the host plant by increasing the photosynthetic efficiency. In addition, these authors point out that some endophytes may favor the survival of plants under conditions of drought, salinity, and / or induce resistance to phytopathogens. Among these microorganisms, the endophytic dark septate fungi, characterized by the presence of a septate and a melanized hyphae, are able to promote growth, inhibit phytopathogenic agents (RIBEIRO et al., 2011; YAN et al., 2015), and influence the mycorrhizal-plant symbiosis. Therefore, depending on microbial interaction and environmental conditions, all these factors may contribute to the host plant's growth, (LINGFEI; ANNA; ZHIWEI, 2005).

In the existing literature, there are no studies related to the interaction of the diazotrophic bacteria, the mycorrhizal fungi, and the endophytic dark septate fungi in the development of gliricidia. Therefore, the objective of this study was to evaluate the interaction of these endophytic microorganisms in the development of the biomass of Gliricidia sepium, grown in a greenhouse.

\section{MATERIAL AND METHODS}

The experimental design was a completely randomized (DIA) and was composed of six treatments (control - without mycorrhizal, native microbial inoculant, and four isolates of arbuscular mycorrhizal fungi (with four replicates): UFLA05 - Gigaspora albida (Schenck \& Smith), UFLA351 - Rhizoglomus clarum (Nicolson \& Schenck) Sieved. Silva \& Oehl, UFLA372 - Claroideoglomus etunicatum (Becker \& Gerd.) Walker \& Schüßler, and UFLA401 - Acaulospora morrowiae Spain \& Schenck), with four replicates.

The experiment was conducted from August to December 2016, in the municipality of São Cristóvão, Sergipe - Brazil, where the climate is classified as tropical with dry summer and rainy winter, according to Köppen (ALVARES et al., 2014).

The isolates of arbuscular mycorrhizal fungi UFLAs were donated by the Laboratory of Soil Microbiology, belonging to the Federal University of Lavras. The native microbial inoculant was obtained from a collection of $3 \mathrm{~kg}$ of rhizospheric soil from an adult gliricidia cultivated in an area adjacent to the Department of Agronomic Engineering, at the Federal University of Sergipe, Campus de São Cristóvão, Sergipe, Brazil.

The multiplication of the UFLAs mycorrhizal isolates was performed on a substrate based on sandy soil autoclaved at $120^{\circ} \mathrm{C}$ and $1 \mathrm{~atm}$ for one hour and repeated after $24 \mathrm{~h}$. The autoclaved soil was distributed in disinfested plastic vessels with $0.5 \%$ sodium hypochlorite for 20 minutes in a 2:1 ratio (sand: mycorrhizal inoculum). The inoculant, composed of spores of mycorrhizal fungi, colonized root fragments, and sand, was distributed among the layers of the autoclaved sand. Seeds of Sorghum 
bicolor L. Moench, was sown and the incubated in a greenhouse with micro sprinkler irrigation. After 60 days of cultivation, the aerial part of the sorghum was cut and the irrigation suspended for 15 days to stimulate sporulation.

The multiplication of the native mycorrhizal inoculant was carried out by incubation of the rhizospheric soil collected from an adult gliricidia, in a covered plastic tray, without irrigation or the host plant, for induction of sporulation for 25 days.

To obtain the seedlings the gliricidia, the seeds were submitted for disinfestation by treating with $70 \%$ alcohol for one minute, followed by immersion in $0.1 \%$ sodium hypochlorite solution for one minute, with a subsequent triple wash in autoclaved distilled water, for one minute (ALFENAS; MAFIA, 2007). The disinfested seeds were arranged on an autoclaved filter paper to remove the excess water and then transferred to gearbox type plastic boxes containing approximately $200 \mathrm{~g}$ of autoclaved sandy soil. The plastic boxes with the soil and the seeds were transferred to a incubator maintained at a temperature of $25 \pm 1{ }^{\circ} \mathrm{C}$, with photoperiod of 10 hours of light, until the seedlings reached the final two pairs of leaves. Next, the seedlings were transplanted into disposable $50 \mathrm{~mL}$ plastic cups containing autoclaved sandy soil and incubated in the incubator for another six days under the same conditions described for germination. Every two days, $2.0 \mathrm{~mL}$ of autoclaved distilled water was applied per cup. On the sixth day, the plastic cups with the sandy soil and the seedlings were transferred to a greenhouse for acclimatization for seven days.

After the acclimation period, the seedlings were transplanted into $500 \mathrm{~mL}$ disposable plastic cups, and autoclaved sandy soil mixed with $50 \mathrm{~g}$ of microbial inoculant was added. The inoculant was composed of soil, spores from the mycorrhizal isolates, and root fragments of the mycorrhizal multiplier host plant. The sandy soil that used was classified as sandy-loam with a $\mathrm{pH} 6.9,4.7 \mathrm{~g} \mathrm{~kg}^{-1}$ organic matter, 1.3 cmolc $\mathrm{dm}^{-3}$ CTC, $76.5 \% \mathrm{~V}$, $8.0 \mathrm{mg} \mathrm{kg} \mathrm{mg}^{-1}$ of potassium, and $8.0 \mathrm{mg} \mathrm{kg}^{-1}$ phosphorus.

The number of spores in the inoculants of UFLA05, UFLA351, UFLA372, and UFLA401 was, on average, 35.7 spores per $50 \mathrm{~g}$ of soil. In the native microbial inoculant, the number of spores of the arbuscular mycorrhizal fungi was 76.7 spores per $50 \mathrm{~g}$ of soil. The number of spores of the mycorrhizal fungi used as an inoculant was determined according to Gerdemann and Nicolson (1963).

The gliricidia seedlings were transplanted from cups to soil and inoculant, according to the specified treatments and distributed randomly in the greenhouse and cultivated for 90 days. The humidity of the greenhouse was maintained through irrigation by micro sprinkler, with flow rate of 45 liters per hour. The irrigation was triggered for one minute, four times a day, with an interval of three hours. The covering fertilization was carried out in the soil around the plants 21 days after transplant and inoculation, by the addition of $3.0 \mathrm{~mL}$ of a solution prepared with $10.0 \mathrm{~g} \mathrm{~L}^{-1}$ of a commercial fertilizer diluted in distilled water. This was repeated weekly for up to 60 days post inoculation. The chemical composition of the commercial fertilizer applied was $13 \%$ nitrogen $(\mathrm{N}), 5 \%$ phosphorus $\left(\mathrm{P}_{2} \mathrm{O}_{5}\right), 13 \%$ potassium $\left(\mathrm{K}_{2} \mathrm{O}\right), 5 \%$ sulfur, $1 \%$ calcium, $0.2 \%$ iron, $0.15 \%$ zinc, $0.08 \%$ manganese, $0.04 \%$ boron, $0.05 \%$ copper, and $0.005 \%$ molybdenum. After 20 days of inoculation, a leaf application of $2.0 \mathrm{~g} \mathrm{~L}^{-1}$ of copper sulfate was carried out to control bacterial blight.

The gliricidia cultivated in the greenhouse were evaluated for the following: plant height, the number of branches, shoot and root dry mass matter, root length and volume, leaf phosphorus levels, mycorrhizal dependency, mycorrhizal colonization, presence of endophytic dark septate fungi, the number of nodules of nitrogen fixing bacteria, and the number of mycorrhizal spores, after 95 days at inoculation. The surrounding field was evaluated for the presence of any endophytic microorganisms from the leaf tissue of an adult gliricidia.

To determine the height of the plant, a millimeter ruler was used and the measurements were made from the lap of the plant to its main bifurcation. The number of branches was obtained by direct counting. The root length was determined with a millimeter ruler and the root volume was analyzed by the principle of water displacement. The root cut at the height of the colon, was washed in running water and then transferred to a beaker containing $500 \mathrm{~mL}$ of distilled water. The volume of the displaced water was recorded. The resulting difference in volume was calculated (in $\mathrm{mL}$ ). The shoot and root dry mass matter were determined using a semi-analytical balance after cutting at the height of the colon and drying the plant material in a forced air circulation oven at $60^{\circ} \mathrm{C}$ until constant weight was attained.

The mycorrhizal dependency (MD) was evaluated for each parameter including, the number of branches, the shoot and root dry mass matter, the root length and volume, with respect to the control (without inoculation), using equation 1 : $M D(\%)=\lceil(M P-C P) / P M\rceil x 100, \quad$ where $\mathrm{PM}=$ value of the parameter analyzed in the mycorrhizal plant and PC = value of the parameter analyzed in the control plant (without mycorrhizal). The mycorrhizal dependency has been classified by Machineski, Ballot and Souza (2011), where plants that presented values $>75 \%$ were classified as excessively dependent; from 50 to $75 \%$ as highly dependent; 25 to $50 \%$ as moderately dependent, and $<25 \%$ as marginally dependent or not respondent to inoculation.

The leaf phosphorus content of the gliricidia 
was determined after drying the leaves in a forced air circulation oven at $60^{\circ} \mathrm{C}$ for three days. Afterwards, the leaves were ground in a knife mill with a $1 \mathrm{~mm}$ diameter sieve and submitted for the analysis of its phosphorus content, according to Malavolta, Vitti and Oliveira (1997).

To assess colonization, the intersection method was used, according to Giovannetti and Mosse (1980). The percentage of mycorrhizal colonization (MC) was calculated using equation 2: $M C(\%)=(T N C R F / T N C) \times 100$, where $\mathrm{TNCRF}$ is the total number of colonized root fragments and TNC is the total number of colonized and non-colonized root fragments. The intensity of mycorrhizal colonization (IMC) was evaluated from the root fragment analysis, as a function of the number of structures such as hyphae, vesicles, arbuscules, appressorium, and spores, according to a subjective scale: $(+)$ presence of the 1 to 5 structures; $(++)$ presence of 5 to 10 structures; $(+++)$ presence of 10 to 20 structures; $(+++++)$ presence of $>20$ structures. The number of spores in the tested mycorrhizal isolates were evaluated in $50 \mathrm{~g}$ of the culture substrate by the wet sieving method according to Gerdemann and Nicolson (1963).

The number of nitrogen fixing bacteria nodules and the presence of endophytic dark septate fungi in all treatments, since they may be associated with the seeds was determined. The number of nodules of nitrogen fixing bacteria was evaluated by direct counting at the root level. The nodulation rate (TNOD) of the nitrogen-fixing bacteria in the mycorrhizal treatments was evaluated in relation to the control, by equation 3 : TNOD $(\%)=[(N O D m p-N O D c p) / N O D m p] \times 100$, where NODmp is the number of mycorrhizal plant nodules, and NODcp is the number of control plant nodules. The presence of an endophytic dark septate was calculated as a percentage in relation to the number of root fragments analyzed, as previously described by Ribeiro et al. (2011).

The endophytic microorganisms present in the leaf tissue of the gliricidia from which the rhizospheric soil was collected to be used as a native inoculant, were isolated according to the methodology of Ribeiro et al. (2011), with some modifications. The endophytes were isolated in a commercial potato-dextrose-agar medium (39.0 $\left.\mathrm{g} \mathrm{L}^{-1}\right)$, after disinfestation by immersing the leaf fragments $\left(0.25 \mathrm{~mm}^{2}\right)$ in alcohol for 1 minute, followed by immersion in $0.1 \%$ sodium hypochlorite for 1 minute, and then triple washed in autoclaved distilled water (1 minute per wash). The incubation was performed in the incubator at $25 \pm 1{ }^{\circ} \mathrm{C}$, without any photoperiod, for 7 days. In the culture medium, two distinct bacterial colonies were grown, whose taxonomic identification was performed by sequencing the Ribosomal 16S Gene (16S rRNA), following standard operating procedure BS.ME.017, at Embrapa Soja, Londrina, Paraná, Brazil, with certificate of analysis (CAS n.001/16).

The results were submitted for an Analysis of Variance (ANOVA) and in the cases where there was a significant difference, the Tukey Test was applied at $5 \%$ of significance to compare the means. In the correlation analysis between the evaluated parameters, the t-Test was applied. The correlation and variance analyses were performed using the Assistat program.

\section{RESULTS AND DISCUSSION}

The mycorrhizal colonization of the gliricidia ranged from 58.6 to $82.7 \%$ when treated with native and UFLAs, with no difference between native inoculant and UFLAs tested (Table 1). Likewise, Sugai, Collier and Saggin-Júnior (2011) observed a high rate of mycorrhizal colonization of Anadenanthera macrocarpa (Benth) Brenam, with no difference between native and mycorrhizal isolates when tested on anthropic soil. These authors cited that this result may have been due to the absence of any diversity in the native arbuscular mycorrhizal fungi species in the anthropic soils. These authors also failed to identify the native microbial community and proposed the existence of one or more mycorrhizal species, similar to our work with gliricidia.

In gliricidia the values of mycorrhizal colonization observed to be above $50 \%$ is classified as high (CARNEIRO et al., 1998) and were similar to those found by Fagbola et al. (2001) on gliricidia inoculated with Glomus deserticola. However, Twum-Ampofo (2008) observed that the mycorrhizal colonization of gliricidia with Glomus clarum (92.2 to $96.4 \%$ ) was significantly higher than the values observed with $G$. etunicatum (35.9 to $77.4 \%$ ) and Gigaspora rosea (32.8 to $45.3 \%$ ), which differs from the results obtained with the isolates UFLA351, UFLA372 and UFLA05, which did not present significant difference (Table 1). 
Table 1. Mycorrhizal colonization (MC), hyphae (H), vesicles (V), intensity mycorrhizal colonization (IMC), number of spores (NE), presence of endophytes dark septate fungi (DSE), number of bacteria nodules nitrogen fixation by root (NOD), nodulation rate (NODT) in gliricidia, after 95 days of mycorrhizal inoculation.

\begin{tabular}{|c|c|c|c|c|c|c|c|c|}
\hline Treat. $^{1}$ & $\begin{array}{l}\text { MC } \\
(\%)\end{array}$ & $\begin{array}{c}\text { H } \\
(\%)\end{array}$ & $\begin{array}{c}V \\
(\%) \\
\end{array}$ & ICM & NE & $\begin{array}{l}\text { DSE } \\
(\%)\end{array}$ & NOD & $\begin{array}{c}\text { NODT } \\
(\%)\end{array}$ \\
\hline Control & $3.8 b^{2}$ & $50.0 \mathrm{ab}$ & $0.0 \mathrm{~b}$ & $t^{3}$ & $395.3 \mathrm{ab}$ & $15.5 \mathrm{a}$ & $35.5 \mathrm{a}$ & \\
\hline Native & $82.7 \mathrm{a}$ & $47.6 \mathrm{ab}$ & $80.2 \mathrm{a}$ & ++++ & $347.6 \mathrm{ab}$ & $17.0 \mathrm{a}$ & $71.5 \mathrm{a}$ & 50.0 \\
\hline UFLA05 & $75.1 \mathrm{a}$ & $27.3 \mathrm{~b}$ & $88.1 \mathrm{a}$ & +++ & $544.0 \mathrm{a}$ & $28.8 \mathrm{a}$ & $49.2 \mathrm{a}$ & 7.0 \\
\hline UFLA351 & $58.6 \mathrm{a}$ & $95.9 \mathrm{a}$ & $22.9 \mathrm{~b}$ & +++ & $174.3 \mathrm{~b}$ & $17.6 \mathrm{a}$ & $42.5 \mathrm{a}$ & 2.0 \\
\hline UFLA372 & $77.2 \mathrm{a}$ & $19.0 \mathrm{~b}$ & $93.7 \mathrm{a}$ & ++++ & $419.6 \mathrm{ab}$ & $18.6 \mathrm{a}$ & $57.0 \mathrm{a}$ & 35.7 \\
\hline UFLA401 & $71.2 \mathrm{a}$ & $21.6 \mathrm{~b}$ & $86.7 \mathrm{a}$ & ++++ & $312.0 \mathrm{ab}$ & $18.4 \mathrm{a}$ & $63.0 \mathrm{a}$ & 40.0 \\
\hline$\overline{C V}(\%)$ & 26.8 & 54.0 & 22.1 & & 24.5 & 43.8 & 20.5 & \\
\hline
\end{tabular}

${ }^{1}$ Treatments: Control, Native, UFLA 05 - G. albida, UFLA 351 - R. clarum, UFLA 372 - C. etunicatum and UFLA $401-$ A. morrowiae $;{ }^{2}$ Averages followed by the same letter in the column do not differ by the Tukey test at $5 \%$ probability; and ${ }^{3}$ Scale of intensity of mycorrhizal structures per root fragment: $(+)=1$ to $5 ;(++)=5$ to $10 ;(+++)=10$ to 20 and $(+++++)>20$

Jalonen et al. (2013) observed that the greatest mycorrhizal colonization of gliricidia occurred up to $1 \mathrm{~m}$ away from the plant, probably due to the fact that the roots here are metabolically more active (ANGELINI et al., 2012). Thus, the cultivation of gliricidia in the $500 \mathrm{~mL}$ plastic cups may have favored high colonization, due to the lower depth and distance of the roots, even in the substrates with low organic matter and phosphorus content (Table 1).

The gliricidia inoculated with UFLA351 presented a mycorrhizal colonization with a higher percentage of hyphae compared UFLA05, UFLA372, and UFLA401 treatment, but did not show any difference compared to the control and the native inoculant (Table 1). The presence of this extra-radicular hyphae probably increased the area of water and nutrient absorption favoring the development of the plant (AUGÉ, 2001; SUGAI; COLLIER; SAGGIN-JÚNIOR, 2011). Moreover, the higher percent of hyphae also contributed to the formation of micro aggregates, which are important in the conservation of soil (RUBIN; STÜRMER, 2015), thereby facilitating the recovery of degraded areas.

Inoculation with UFLA05, UFLA372, UFLA401, and native the inoculant resulted in a higher percentage of vesicles than with the control and UFLA351 (Table 1). The presence of these vesicles in the UFLA05 was characterized by a contamination from the isolates UFLA351, UFLA372 and/or native, because this structure is characteristic of the genus Glomus and Paraglomus (MOREIRA; SIQUEIRA, 2006). The lower percentage of vesicles in the gliricidia inoculated with UFLA351 may be associated with a low organic matter content in the culture substrate (Table 1). Jalonen et al. (2013), and Stürmer and Siqueira (2008) mentioned that carbon limitation often reduced the percentage of vesicles, a glycogen granules and lipids storage structure in fungi. However, the limitation of carbon and phosphorus in the culture substrate did not influence the intensity of colonization of gliricidia with the native treatments including UFLA372 (C. etunicatum) and UFLA401 (Table 1), suggesting that the formation of vesicles may depend on the AMF-plant interactions.

Evaluation of the fragments of the roots of gliricidia did not reveal any arbuscules, probably due to the presence of thick roots, which increases makes identification of this structure difficult. Similar obstacle was also reported by Sugai, Collier and Saggin-Júnior (2011) in their study on Anadenanthera macrocarpa (Benth) Brenam. However, Ferdousee, Misbahuzzaman and Hoque (2012) have reported the presence of arbuscules in gliricidia. Moreover, Walter et al. (2016), and earlier Mandyam and Jumpponen (2008), cited that the arbuscules are formed in poaceae under extreme environmental conditions, such as drought/excess rainfall or due to the seasonality. However, for Fabaceae spp. no such association between the time of the year and the formation of the arbuscules have been reported.

Mello, Silva and Saggin-Júnior (2012) emphasized that any evaluation of the functional compatibility between arbuscular mycorrhizal fungi and plants, should consider the sporulation capacity in the rhizosphere. In this context, the sporulation was 365.5 spores per $50 \mathrm{~g}$ of soil, on an average, without measurable difference between the treatments, except between UFLA05 (544 spores/50g) and UFLA351 (174, 3 spores/50g) (Table 1). Ferdousee, Misbahuzzaman and Hoque (2012) reported that the sporulation of the native mycorrhizal isolates inoculated in gliricidia was 60 spores per 100 grams of the substrate, with the presence of the genera Glomus, Acaulospora, and Entrophospora in the soil at a $\mathrm{pH}$ of 5.8. These authors mentioned that the Acaulospora is more tolerant to acidic $\mathrm{pH}$, whereas Glomus species prefer neutral to alkaline soils. Such preferences may also influence the AMF-plant interaction, since the $\mathrm{pH}$ of the cultivation substrate was kept at 6.9 on our study. The presence of high humidity in the incubation oven during the experiment might have stimulated 
the sporulation of the fungal isolates tested.

The gliricidia was also colonized by the endophytic dark septate fungi without any detectable difference between the treatments (Table 1).
However, the presence of these endophytes did not influence the mycorrhizal colonization, except in the control treatment that presented a positive correlation (Table 2).

Table 2. Correlation coefficient (r) between number of nodules (NOD), dark septate (DSE), mycorrhizal colonization (MC) and vesicles (VES) in roots gliricidia.

\begin{tabular}{lcccccc}
\hline \multirow{2}{*}{ Parameters } & \multicolumn{5}{c}{ Correlation coefficient (r) } \\
\cline { 2 - 6 } & Control $^{1}$ & Native & UFLA05 & UFLA351 & UFLA372 & UFLA401 \\
\hline MC x DSE & $0.9999^{* *}$ & $\mathrm{~ns}$ & $\mathrm{~ns}$ & $\mathrm{~ns}$ & $\mathrm{~ns}$ & $\mathrm{~ns}$ \\
MC x NOD & $\mathrm{ns}$ & $\mathrm{ns}$ & $\mathrm{ns}$ & $\mathrm{ns}$ & $\mathrm{ns}$ & $\mathrm{ns}$ \\
VES x NOD & $\mathrm{ns}$ & $\mathrm{ns}$ & $\mathrm{ns}$ & $\mathrm{ns}$ & $\mathrm{ns}$ \\
NOD x DSE & $\mathrm{ns}$ & $\mathrm{ns}$ & $\mathrm{ns}$ & $\mathrm{ns}$ & $\mathrm{ns}$ & $\mathrm{ns}$ \\
\hline
\end{tabular}

${ }^{1}$ Treatments: Control, Native, UFLA 05 - G. albida, UFLA 351 - $R$. clarum, UFLA 372 - C. etunicatum and UFLA $401-$ A. morrowiae $^{2}(\mathrm{~ns})$ without significant, $\left({ }^{*}\right)$ significant at $5 \%$ and $(* *)$ significant at $1 \%$ probability by Test $\mathrm{t}$.

Additionally, the gliricidia was colonized by nitrogen-fixing bacteria, without any significant difference in the number of nodules produced with or without the mycorrhiza, even though were not inoculated with the nitrogen-fixing bacteria. Compared to the control, the presence of the nitrogen fixing bacteria nodules was about $50 \%$ in the native inoculant treated. In this treatment, the nitrogenfixing bacteria nodules may have occurred due to the use of rhizospheric soil of the non-autoclaved as an inoculant of the gliricidia. Compared to the controls, the inoculation with the isolates from UFLA372 and UFLA401 favored an increase in nodulation up to 35.7 and $40.0 \%$, respectively. In gliricidia inoculated with UFLA05 and UFLA351 the increase in nodulation was 7.0 and $2.0 \%$ respectively. In these treatments, the nodules of nitrogen-fixing bacteria were produced by an internal colonization of the seeds of the gliricidia by the bacteria. In addition, the lowest increase in the nodulation obtained with UFLA05 and UFLA351 treatment, was attributed to the smaller increment of mycorrhizal structures (ICM) observed in the gliricidia inoculated with these mycorrhizal isolates (Table 1). This observation differs from the results cited by Mello, Silva and Saggin-Júnior (2012), where they found that $G$. clarum stimulated more than five times the nodulation of the arboreal legume, Mimosa artemisiana compared to inoculation free control.

There was no correlation between the mycorrhizal colonization and the number of nodules of the nitrogen fixing bacteria in all the treatments. The observed high percentage of vesicles did not correlate with the number of nodules, except for UFLA401treatment, that presented negative correlation between these two parameters (Table 2). There was probably an antagonistic action between the mycorrhizal isolate and the nitrogen fixing bacteria. Similarly, Twum-Ampofo (2008) reported that the mycorrhizal colonization of gliricidia by
Glomus clarum, G. etunicatum, G. intraradices, and Gigaspora rosea was inhibited by the inoculation of Rhizobium strains.

From the leaf tissue of the gliricidia growing in the fields, two endophytic bacteria namely, Paenibacillus illinoisensis and Pantoea stewartii were isolated. These bacterial species might be present in the soil of the native inoculant used for this work. In the literature, no interaction between gliricidia and $P$. stewartii or $P$. illinoisensis have been found. However, the presence of such asymptomatic bacteria in the plant may characterize a beneficial interaction as mentioned by Santos and Varavallo (2011).

According to Silva et al. (2016), the endophytic bacteria $P$. stewartii, isolated from sugar cane presented the ability to fix nitrogen and to solubilize the inorganic phosphate in the soil, which can positively influence the biomass of the gliricidia and mask the effects of the mycorrhizal inoculants tested. The endophytic bacteria $P$. illinoisensis produces chitinases, which can inhibit or degrade mycelium of phytopathogenic fungi such as Rhizoctonia solani, Fusarium solani, and Sclaretium rolfsi (SUBBANNA; KHAN; SHIVASHANKARA, 2016) thus ensuring the survival of the gliricidia in the field.

However, inoculation of the gliricidia with the native microbiota and UFLAs did not increase the height of plant, number of branches, or the shoot and root dry mass matter when compared to the control (Table 3). Similar findings were reported by Walter et al. (2016), with another fabaceae, namely the Holcus lanatus, which was inoculated with arbuscular mycorrhizal fungi. One potential explanation for these results could be the diversity in the microorganisms found in all the treatments, namely, mycorrhizal isolates, endophytic dark septate fungi, and nitrogen-fixing bacteria, that when interacting with one another, may be antagonistic or 
not (YAN et al., 2015). Graham et al. (1982) mentioned that the mycorrhizal colonization of a plant does not increase its biomass, but depends on the fungi-plant interaction. Among the parameters analyzed, despite the absence of any difference, the use of the UFLA401 treatment increased the number of branches by $37.6 \%$ compared to the control, thus contributing to vegetative propagation (Table 3 ).

Table 3. Height plant $(\mathrm{H})$, number of branches (NB), shoot dry mass matter (SDMM), root dry mass matter (RDMM), root length (RL), root volume (RV) and leaf phosphorus (P leaf) of Gliricidia sepium inoculated with FMAs, after 95 days of inoculation.

\begin{tabular}{lccccccc}
\hline Treat. & $\begin{array}{c}\text { H } \\
(\mathbf{c m})\end{array}$ & NB & $\begin{array}{c}\text { SDMM } \\
(\mathbf{g})\end{array}$ & $\begin{array}{c}\text { RDMM } \\
(\mathbf{g})\end{array}$ & $\begin{array}{c}\text { RL } \\
(\mathbf{c m})\end{array}$ & $\begin{array}{c}\text { RV } \\
(\mathbf{m L})\end{array}$ & $\begin{array}{c}\text { P leaf } \\
\left(\mathbf{g ~ K g} \mathbf{K g}^{-1}\right)\end{array}$ \\
\hline Control & $14.1 \mathrm{a}^{2}$ & $8.5 \mathrm{a}$ & $1.6 \mathrm{a}$ & $1.2 \mathrm{a}$ & $11.2 \mathrm{ab}$ & $11.7 \mathrm{a}$ & $2.1 \mathrm{a}$ \\
Native & $20.0 \mathrm{a}$ & $9.7 \mathrm{a}$ & $2.8 \mathrm{a}$ & $2.4 \mathrm{a}$ & $13.1 \mathrm{ab}$ & $18.0 \mathrm{a}$ & $1.9 \mathrm{a}$ \\
UFLA05 & $13.7 \mathrm{a}$ & $6.7 \mathrm{a}$ & $1.8 \mathrm{a}$ & $1.4 \mathrm{a}$ & $12.0 \mathrm{ab}$ & $13.7 \mathrm{a}$ & $3.6 \mathrm{a}$ \\
UFLA351 & $16.0 \mathrm{a}$ & $9.5 \mathrm{a}$ & $2.1 \mathrm{a}$ & $1.8 \mathrm{a}$ & $10.5 \mathrm{~b}$ & $15.0 \mathrm{a}$ & $5.1 \mathrm{a}$ \\
UFLA372 & $17.6 \mathrm{a}$ & $8.7 \mathrm{a}$ & $2.3 \mathrm{a}$ & $2.1 \mathrm{a}$ & $14.1 \mathrm{a}$ & $15.7 \mathrm{a}$ & $7.0 \mathrm{a}$ \\
UFLA401 & $19.2 \mathrm{a}$ & $11.7 \mathrm{a}$ & $2.8 \mathrm{a}$ & $1.8 \mathrm{a}$ & $11.5 \mathrm{ab}$ & $17.2 \mathrm{a}$ & $1.5 \mathrm{a}$ \\
\hline CV (\%) & 20.8 & 18.8 & 25.5 & 21.0 & 13.7 & 22.9 & 59.7 \\
\hline
\end{tabular}

${ }^{1}$ Treatments: Control, Native, UFLA 05 - G. albida, UFLA $351-R$. clarum, UFLA $372-C$. etunicatum and UFLA $401-A$. morrowiae; and ${ }^{2}$ Means followed by the same letter in the column not differ by the Tukey test at $5 \%$ probability.

Analyzing the phosphorus content in the leaves, an inoculation with UFLA05, UFLA351, and UFLA372 resulted in an increase of $171.4 \%$, $242.9 \%$, and $333.3 \%$ respectively compared to controls. However, no difference in the leaf phosphorus content was noted the mycorrhizal treatment (Table 3). Similar finding was previously reported by Twum-Ampofo (2008) with the Glomus sp. This increase in the leaf phosphorus content may contribute to the systemic defense mechanism, as mentioned by Gerlach et al. (2015) with corn plants, which may be an important factor for survival in the field.

Treatment with the isolate from UFLA351 presented a lower root length in the gliricidia compared to treatment with UFLA372, but without a significant difference in the root length and volume relation to other treatments (Table 3 , Figures $1 \mathrm{~b}$ and 1e). This was probably due to the formation of fine secondary roots. The presence of fine secondary roots may contribute to a greater resistance to soil shear (MACHADO et al., 2015) and favor soil and water conservation.

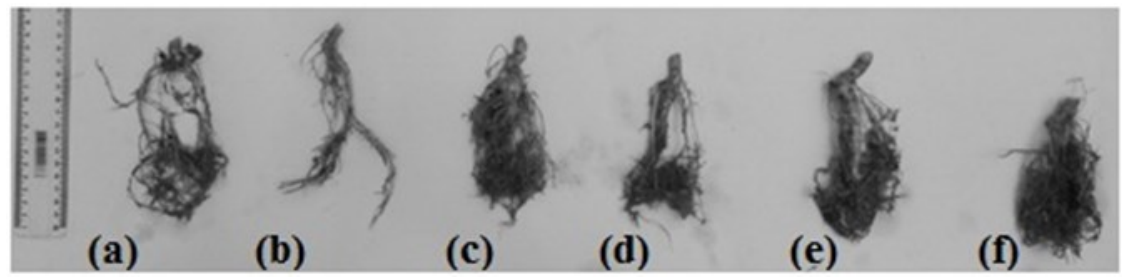

Figure 1. Roots gliricidia colonized by arbuscular mycorrhizal fungi*, after 95 days of inoculation.

*Treatments: (a) Control, (b) UFLA351 - R. clarum, (c) native, (d) UFLA05 - G. albida, (e) UFLA372 - C. etunicatum and (f) UFLA401 - A. morrowiae.

The root dry mass matter of the gliricidia treated with the native inoculant and UFLAs did not correlate with the mycorrhizal colonization, the number of nodules, and the presence of any endophytic dark septate fungi. In the control treatment, a mycorrhizal colonization of $3.8 \%$ and the presence of endophytic dark septate fungi in $15.5 \%$ of the root fragments, showed a negative correlation with the root dry mass matter, supporting an inhibition in the formation of the root biomass (Tables 1 and 4 ).

The correlation between an increase in the biomass and mycorrhizal colonization depends on the fungi-plant interaction (MOREIRA; SIQUEIRA,
2006), but it is important to note that the efficiency of the symbiosis is not always correlated to a high mycorrhizal colonization (GRAHAM et al., 1982), as observed in this work with the native inoculant and UFLAs. However, it should be considered that the gliricidia may have been colonized by endophytic bacteria, such as Pantoea stewartii and Paenibacillus illinoisensis, arbuscular mycorrhizal fungi, endophytic dark septate fungi, and nitrogen-fixing bacteria, and that the isolated evaluation of only one of the symbiotic microorganisms did not permit the evaluation of all the microbial interactions that contribute to the development of the dry matter mass of the root. 
Table 4. Correlation coefficient (r) of root dry mass matter (RDMM), number of nodules (NOD), mycorrhizal colonization (MC), dark septate endophytic (DSE) obtained in inoculated Gliricidia sepium with arbuscular mycorrhizal fungi.

\begin{tabular}{lcccccc}
\hline \multirow{2}{*}{ Parameters } & \multicolumn{5}{c}{ Correlation coefficient (r) } \\
\cline { 2 - 6 } & Control & Native & UFLA05 & UFLA351 & UFLA372 & UFLA401 \\
\hline RDMM x MC & $-0.9719 *$ & $n s$ & $n s$ & $n s$ & $n s$ & $n s$ \\
RDMM x NOD & $n s$ & $n s$ & $n s$ & $n s$ & $n s$ \\
RDMM x DSE & $-0.9719 *$ & $n s$ & $n s$ & $n s$ & $n s$ \\
\hline
\end{tabular}

${ }^{1}$ Treatments: Control, Native, UFLA 05 - G. albida, UFLA 351 - R. clarum, UFLA 372 - C. etunicatum and UFLA 401 - A. morrowiae; ${ }^{2}(\mathrm{~ns})$ without significant, $(*)$ significant at $5 \%$ and $(* *)$ significant at $1 \%$ probability by Test $\mathrm{t}$.

In relation to the endophytic fungi, Santos and Varavallo (2011) proposed that these microorganisms are growth promoters and can be used for the biological control of pathogens, but Yan et al. (2015) suggested that the endophytic bacteria may be antagonistic to other species of microorganisms and therefore, negatively influence the interaction of the mycorrhizal fungi, and, consequently impact the vegetal development of gliricidia.

Literature strongly supports that the mycorrhizal dependency evaluates how much the plant responds to the inoculation but all the data is only in terms of the total dry mass matter. In this work, the dependency was also evaluated for the number of branches, shoot and root dry mass matter, root length and volume, which allows one to evaluate the influence of microorganisms on plant growth with greater precision. In this context, the gliricidia was responsive to the use of the native inoculant according Machineski, Balota and Souza
(2011), because it presented a $39.4 \%$ increase in the shoot dry mass matter, $45.6 \%$ increase in the root dry mass matter, and $31.4 \%$ increase in the root volume. The use of the isolate UFLA372 favored a $39.7 \%$ increase in root dry mass matter, and gliricidia should be considered responsive only to this parameter. Treatment with UFLA401, increased the number of branches by $27.3 \%$, the shoot dry mass matter by $27.0 \%$, and the root volume by $25.8 \%$ and the gliricidia was responsible for the inoculation of this isolate. The gliricidia was not responsive to the inoculation of the isolates from UFLA05 and UFLA351, due to the mycorrhizal dependency being lower than $25 \%$ in the tested parameters namely, the number of branches, shoot and root dry mass matter, root length, and volume (Figure 2). This result may have been due to the presence of a diverse group of microorganisms in addition to the mycorrhizal inoculant, which may inhibit or stimulate mycorrhizal dependency of the fungi-plant interaction (YAN et al., 2015).

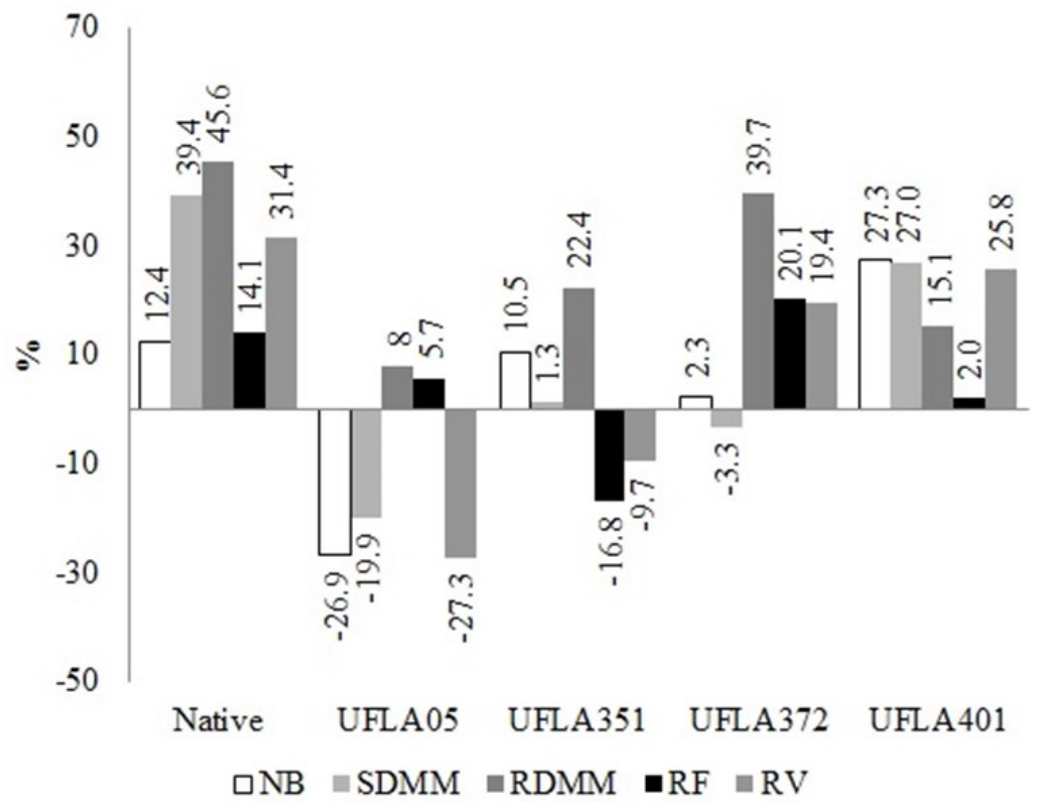

Figure 2. Mycorrhizal dependency of gliricidia with arbuscular mycorrhizal fungi* in relation to the number of branches (NB), shoot dry mass matter (SDMM), root dry mass matter (RDMM), root length (RL) and root volume (RV).

*Treatments: Control, Native, UFLA 05 - G. albida, UFLA 351 - R. clarum, UFLA 372 - C. etunicatum and UFLA 401 - $A$. morrowiae.

The effect of microbial interaction on the development of gliricidia biomass may have been influenced by the time of cultivation as observed by
Mello, Silva and Saggin-Júnior (2012), with the fabaceae tree, Mimosa artemesiana. Sugai, Collier and Saggin-Júnior (2011) observed a synergism 
between the arbuscular mycorrhizal fungi and the nitrogen-fixing bacteria, but this cooperation may be influenced by other microorganisms and soil type (natural or anthropic). Thus, studies on gliricidia and the association of mycorrhizal fungi, nitrogen fixing bacteria, and endophytic dark septate fungi should be explored, since they may contribute to the a better utilization of this fabaceae in the recovery of degraded areas, as well as an important source of nutrients for the animals under drought conditions, mainly in the Northeastern Brazil.

\section{CONCLUSIONS}

The gliricidia is responsive to the inoculation of the native microbiota, UFLA372 (Claroideoglomus etunicatum) and UFLA401 (Acaulospora morrowiae), but is not responsive to the inoculation of UFLA05 (Gigaspora albida) and UFLA351 (Rhizoglomus clarum).

Mycorrhizal colonization by Acaulospora morrowiae (UFLA401) was influenced by the presence of a nitrogen-fixing bacteria.

The occurrence of the endophytic dark septate fungi did not inhibit the mycorrhization and the formation of nitrogen fixation bacteria nodules in the gliricidia.

The isolate UFLA401 (Acaulospora morrowiae) resulted in a $27.3 \%$ increase in the number of branches of gliricidia, compared to the control, which may be important in the regrowth rate under field conditions.

In field, the gliricidia is colonized by the two bacteria namely, Paenibacillus illinoisensis and Pantoea stewartii, and this bacteria-plant interaction needs to be further explored.

\section{ACKNOWLEDGMENTS}

The authors thank the researcher Dr. Mariangela Hungria da Cunha, from the Laboratory of Soil Biotechnology, Embrapa Soja, LondrinaParaná-Brazil, for the genetic sequencing of the bacteria isolated from the foliar tissue of the gliricidia.

\section{REFERENCES}

ALFENAS, A. C.; MAFIA, R. G. Métodos em fitopatologia. 1. ed. Viçosa, MG: UFV, 2007. 382 p.

ALVARES, C. A. et al. Köppen's climate classification map for Brazil. Meteorologische Zeitschrift, Stuttgart, v. 22, n .6, p. 711-728, 2014.

ANGELINI, G. A. R. et al. Colonização micorrízica, densidade de esporos e diversidade de fungos micorrízicos arbusculares em solo de cerrado sob plantio direto e convencional. Semina: Ciências Agrárias, Londrina, v. 33, n. 1, p. 115-130, 2012.

AUGÉ, R. M. Water relations, drought and vesicular -arbuscular mycorrhizal symbiosis. Mycorrhiza, New York, v. 11, n. 1, p. 3-42, 2001.

CARNEIRO, M. A. C. et. al. Micorriza arbuscular em espécies arbóreas e arbustivas de ocorrência no sudeste do Brasil. Cerne, Lavras, v. 4, n. 1, p. 129145,1998

EIRAS, P. P.; COELHO, F. C. Utilização de leguminosas na adubação verde para cultura de milho. Revista Científica Internacional, Campos dos Goytacazes, v. 4, n. 17, p. 96-124, 2011.

FAGBOLA, O. et al. Effects of drought stress and arbuscular mycorrhiza on the growth of Gliricidia sepium (Jacq). Walp, and Leucaena leucocephala (Lam.) de Wit. in simulated eroded soil conditions. Mycorrhiza, New York, v. 11, n. 5, p. 215-223, 2001 .

FERDOUSEE, N.; MISBAHUZZAMAN, K.; HOQUE, A. T. M. R. Arbuscular mycorrhizal colonization in five tropical forest tree legumes of Chittagong University Campus in Bangladesh. Journal of Basic \& Applied Sciences, Karachi, v. 8, n. 2 , p. $353-361,2012$.

FLORENTINO, L. A. et al. Diversidade e potencial de utilização dos rizóbios isolados de nódulos de Gliricidia sepium. Revista de Ciências Agrárias, Lisboa, v. 37, n. 3, p. 320-328, 2014.

GERDEMANN, J. W.; NICOLSON, T. H. Spores of mycorrhizal endogone species extracted from soil by wet-sieving and decanting. Transactions of British Mycological Society, Cambridge, v. 46, n. 2, p. 235 244, 1963.

GERLACH, N. et al. An integrated functional approach to dissect systemic responses in maize to arbuscular mycorrhizal symbiosis. Plant, Cell \& Environment, New Jersey, v. 38, n. 8, p. 15911612,2015

GIOVANNETTI, M.; MOSSE, B. An evaluation of techniques for measuring vesicular arbuscular mycorrhizal infection in roots. New Phytologist, Cambridge, v. 84, n. 3, p. 489-500, 1980.

GRAHAM, J. H. et al. Development of external hyphae by different isolates of mycorrhizal Glomus spp. in relation to root colonization and growth of Troyer citrange. New Phytologist, Cambridge, v. 91, n. 1, p. 183-189, 1982. 
JALONEN, R. et al. Arbuscular mycorrhizal symbioses in a cut-and-carry forage production system of legume tree Gliricidia sepium and fodder grass Dichanthium aristatum. Agroforestry Systems, Dordrecht-Netherlands, v. 87, n. 2, p. 319330, 2013.

LINGFEI, L.; ANNA, Y.; ZHIWEI, Z. Seasonality of arbuscular mycorrhizal symbiosis and dark septate endophytes in a grassland site in southwest China. FEMS Microbiology Ecology, Oxford, v. 54, n. 3, p. $367-373,2005$.

MACHADO, L. et al. Contribuição do sistema radicular do capim-vetiver para estabilização do talude do Rio São Francisco. Semina: Ciências Agrárias, Londrina, v. 36, n. 4, p. 2453-2464, 2015.

MACHINESKI, O.; BALOTA, E. L.; SOUZA, J. R. P. Resposta da mamoneira a fungos micorrízicos arbusculares e a níveis de fósforo. Semina: Ciências Agrárias, Londrina, v. 32, n. 4, p. 1855-1862, 2011.

MALAVOLTA, E.; VITTI, G. C.; OLIVEIRA, S. A. Avaliação do estado nutricional das plantas: princípios e aplicações. 2. ed. Piracicaba, SP: Associação Brasileira para Pesquisa do Fosfato, 1997. $238 \mathrm{p}$.

MANDYAM, K.; JUMPPONEN, A. Seasonal and temporal dynamics of arbuscular mycorrhizal and dark septate endophytic fungi in a tallgrass prairie ecosystem are minimally affected by nitrogen enrichment. Mycorrhiza, New York, v. 18, p. 145$155,2008$.

MARIN, A. M. P. et al. Efeito da Gliricidia sepium sobre nutrientes do solo, microclima e produtividade do milho em sistema agroflorestal no agreste paraibano. Revista Brasileira de Ciências do Solo, Viçosa, v. 30, n. 3, p. 555-564, 2006.

MELlO, A. H.; SILVA, E. M. R.; SAGGINJÚNIOR, O. J. Seleção de fungos micorrízicos arbusculares eficientes para promoção do crescimento da leguminosa Mimosa artemisiana Heringer \& Paula. Revista Agroecossistemas, Marabá, v. 4, n. 2, p. 40-51, 2012.

MOREIRA, F. M. S.; SIQUEIRA, J. O. Microbiologia e bioquímica do solo. 2. ed. Lavras, MG: UFLA, 2006. 729 p.

RIBEIRO, K. G. et al. Isolamento, armazenamento e determinação da colonização por fungos "dark septate" a partir de plantas de arroz. Revista Agro@ambiente on-line, Boa Vista, v. 5, n. 2, p. 97 $-105,2011$.
RUBIN, J. G. K. R.; STÜRMER, S. L. Potencial de inóculo micorrízico e importância do comprimento do micélio para agregação de solos de ambiente fluvial. Revista Brasileira de Ciência do Solo, Viçosa, v. 39, n. 1, p. 59-68, 2015.

SANTOS, T. T.; VARAVAllO, M. A. Aplicação de microrganismos endofíticos na agricultura e na produção de substâncias de interesse econômico. Semina: Ciências Biológicas e da Saúde, Londrina, v. 32, n. 2, p. 199-212, 2011.

SILVA, M. O. et al. Bacteria associated with sugarcane in Northeastern Brazil. African Journal of Microbiology Research, Johannesburg, v. 10, n. 37, p. 1586-154, 2016.

STÜRMER, S. L; SIQUEIRA, J. O. Diversidade de fungos micorrízicos arbusculares em ecossistemas brasileiros. In: MOREIRA, F. M. S.; SIQUEIRA, J. O.; BRUSSAARD, L. (Eds.). Biodiversidade do solo em ecossistemas brasileiros. Lavras: UFLA, 2008. cap. 16 , p. 537-583.

SUBBANNA, A. R. N. S.; KHAN, M. S.; SHIVASHANKARA, K. Characterization of antifungal Paenibacillus illinoisensis strains $\mathrm{UKCH} 21$ and its chitinolytic properties. African Journal of Microbiology Research, Johannesburg, v. 10, n. 34, p. 1380-1387, 2016.

SUGAI, M. A. A.; COLLIER, L. S.; SAGGINJÚNIOR, O. J. Inoculação micorrízica no crescimento de mudas de angico em solo de cerrado. Revista Bragantia, Campinas, v. 70, n. 2, p. 416423, 2011.

TAVARES, R. C. et al. Colonização micorrízica e nodulação radicular de mudas de sabiá (Mimosa caesalpinieaefolia Benth.) sob diferentes níveis de salinidade. Revista Ciência Agronômica, Fortaleza, v. 43, n. 3 , p. 409-416, 2012.

TWUM-AMPOFO, T. Growth response of Gliricidia sepium (Jacq.) Walq to inoculation with different arbuscular mycorrhizal (AM) fungi. Journal of Science and Technology, Kumasi, v. 28, n. 2, p. 5468, 2008.

WALTER, J. et al. Effects of extreme weather events and legume presence on mycorrhization of Plantago lanceolata and Holcus lanatus in field. Plant Biology, Berlim, v. 18, n. 1, p. 262-270, 2016.

YAN, J. F. et al. Do endophytic fungi grow throught their hosts systemically? Fungal ecology, Manchester, v. 13, n. 1, p. 53-59, 2015. 